\title{
Impact of Environmental Subsidies on Environmental Technology Innovation of Polluting Enterprises
}

\section{Chunwei Han $\dagger$}

School of Accounting, Henan University of Engineering, Zhengzhou 451191, China

$\nmid$ Corresponding author: Chunwei Han; huehan@126.com

\section{Nat. Env. \& Poll. Tech.} Website: www.neptjournal.com

Received: 12-04-2021

Revised: $30-05-2021$

Accepted: 12-06-2021

Key Words:

Environmental subsidies

Green innovation

Green patent

Strategic innovation

\begin{abstract}
Environmental technology innovation plays an important role in solving pollution control problems. Under the background of the green development of the polluting industry, environmental subsidies have become an important financial instrument to make up for the lack of capital market. To explore the motivation of environmental technology innovation supported by environmental subsidies, using the data of listed polluting enterprises in China from 2013 to 2019, the impact of environmental subsidies on environmental technology patents of polluting enterprises was discussed from the perspective of selective industrial policies. Results show that environmental subsidies stimulate the total number of environmental technology patents and non-invention patents to increase significantly, showing the behavior characteristics of enterprises pursuing innovation quantity while ignoring quality. When enterprises expected to get more environmental subsidies, they make environmental technology patents to seek support. The above phenomenon is only significant in the state-owned enterprise group and senior executives group with a technical background in the group analysis results. The number of environmental technology invention patents of private enterprises increased significantly. The selective environmental subsidies policy stimulates the strategic innovation of enterprises, while the environmental technology invention patents representing substantive innovation and high-quality innovation are not improved significantly. The managerial implication of the conclusions is that the government should not only consider increasing environmental subsidies to polluting enterprises in the future but also should support better regulatory policies to improve the level of pollution prevention and control through environmental technology innovation.
\end{abstract}

\section{INTRODUCTION}

Environmental pollution has become a common problem all over the world. Polluting enterprises as the main emitters of pollutants in the process of economic and social development, should actively increase investment in environmental technology innovation, develop energy-saving and low-carbon advanced environmental protection technology and equipment, comprehensively improve the operation quality of pollution control facilities, and assume the important responsibility of environmental protection. It is generally believed that the externality, indivisibility, and uncertainty of innovation activities would inevitably lead to market failure, thus hindering enterprises from achieving the socially optimal level of spontaneous R\&D activities. In this regard, selective innovation incentives are widely used in the world (Luo et al. 2020). However, it is difficult for the government to effectively supervise the R\&D activities of all applicants, so there is a possibility of adverse selection and moral hazard. This means that in addition to substantial innovation aimed at technology upgrading and competitive advantage, enterprises may also participate in strategic innovation. They aim to cover up the actual innovation ability, to cater to the government and achieve other interests. However, in the initial R\&D stage, enterprises face financing constraints from the capital market, which is also an objective reality. To this end, the Chinese government has arranged a large number of environmental subsidies to encourage environmental technology innovation (Wang et al. 2020).

The existing literature has classified the enterprise environmental technology innovation from the innovation content, innovation intensity, or innovation mode, but less literature analyzed innovation behavior from the perspective of motivation (Li et al. 2016). In fact, in addition to the substantial innovation motivation for core technology breakthrough, enterprises also have the intention of the one-sided pursuit of innovation quantity to meet the industrial policy and seek other interests, which is a kind of "strategic" behavior. Therefore, it is of great academic value and policy significance to study the motivation of different innovation activities for understanding the interaction between the government and enterprises in the implementation process of China's industrial subsidy policy, evaluating the effectiveness of policy implementation, and exploring the mechanism of action. 
Given this, this study attempts to distinguish environmental technology innovation behaviors with different motives and to investigate the impact of environmental subsidies on environmental technology innovation of micro-enterprises and internal mechanisms. The conclusions are expected to provide empirical basis for formulating scientific and effective environmental subsidy policies and give full play to the positive role of environmental technology innovation in environmental protection.

\section{PAST STUDIES}

Theoretically, environmental technology innovation can improve the environmental performance of enterprises, and has a positive contribution to the financial performance of enterprises (Xie et al. 2019). At the same time, environmental subsidies also lead to stronger government regulation and supervision pressure on enterprises, forcing enterprises to enhance the legitimacy of environmental behavior through environmental technology innovation (Li et al. 2017).

However, in enterprise practice, the difference between the "outsider" role of local government and the professional and technical background of enterprise environmental technology innovation makes it difficult for the government to implement effective external governance and intervention mechanism. The impact of environmental subsidies on environmental technology innovation has been independent of government supervision and intervention. Innovation behavior measured by the patent application is typical strategic behavior.

From the perspective of policy implementation, the government has the inertia of directly intervening in the economy and implements the "selective" industrial policy led by the government. For example, the catalog of encouraging industries or the guidance catalog of industrial structure adjustment and other similar documents issued by the government every year had regulatory characteristics of the government choosing to replace market mechanism and restricting competition (Jiang et al. 2010). However, the information asymmetry between policymakers and enterprises, as well as the limitations of professional knowledge and practice, also made it difficult for the government to correctly predict the future of technology. Therefore, for the consideration of being responsible for financial funds, the government had its precondition to issuing subsidies, that was, to select the subsidy object according to innovation signals released by enterprises in advance. At this time, it was easy to induce enterprises to make adverse selection behavior of "seeking support" (Hall et al. 2012, Mao et al. 2015).

From the perspective of the technology cycle and policy timeliness, although the strategic value brought by environmental technology innovation would eventually show higher environmental performance, social performance and behavioral legitimacy, its economic benefits could not be realized in the short term. The goal of local government to implement industrial policies was to achieve short-term results (Jiang et al. 2010). This showed that there were great differences between the short-term goal orientation of China's industrial policy and the long-term sustainable investment needed for substantive innovation. From the perspective of incentive compatibility, enterprises could not achieve effective unification of "private interest" and "public interest" in the short term through environmental technology innovation (Wang et al. 2020).

In addition, the selection system of government officials also provided an institutional basis for enterprises to implement strategic innovation. If local officials wanted to occupy an advantage in the promotion competition, they must make greater achievements in the short period, which conflicted with the long-term nature of substantive innovation. To achieve the short-term achievements, officials chose enterprises with more and faster achievements to provide strong financial support, while enterprises carried out low-level innovation to meet the political needs of officials.

This study divides the environmental technology innovation behavior of enterprises into two types from the perspective of motivation. The one is the behavior of applying for high-level invention patents identified as substantive innovation, which aims to promote technological progress and to obtain a competitive advantage. The other is the act of applying for other patents recognized as strategic innovation, which caters to the supervision by pursuing the quantity of innovation, to seek other interests. Then, this study selects characteristics of industrial policy to investigate the effect and mechanism of environmental subsidies on environmental technology innovation.

\section{METHODOLOGY}

\section{Samples and Data}

This study selects polluting listed enterprises of China's A-share market in Shanghai and Shenzhen from 2013 to 2019 as research samples. The environmental technology patent data are from the State Content of Patent Database of China (SCPD) and the State Intellectual Property Office of China (SIPO). The subsidy comes from the annual report of listed enterprises. The financial data of enterprises come from the CSMAR database.

To reduce the impact of outliers, enterprises under special treatment and samples with missing data of important variables are excluded. Final samples include 1100 enterprises and 6180 effective observations. The observation results 
of the samples in the chemical industry, medicine, metal smelting, electricity, heat, gas and water production and supply, transportation, storage and postal services industries are relatively concentrated, accounting for $14.63 \%, 11.42 \%$, $10.61 \%, 9.9 \%$, and $8.48 \%$, respectively. To eliminate the influence of extreme values, all continuous variables are winsorized at $1 \%$ and $99 \%$ levels. Stata15.0 software was used for all data processing.

\section{Variable Definition}

This study uses environmental technology patent applications to measure the environmental technology innovation behavior of enterprises. The data of "environmental technology innovation" has not been classified and disclosed in the patent database. Therefore, it obtains enterprise environmental technology patent information through keyword screening (Cormier et al. 2015, Yu 2021).

Environmental subsidy refers to the government's special subsidies, special funds, and achievement awards for environmental protection projects such as enterprise environmental governance, environmental protection technology R\&D, energy conservation, and emission reduction. Its content generally includes keywords such as energy conservation and emission reduction, environmental protection, energy, environment technology, waste gas, carbon emissions, carbon trading, recycling, sustainable development, and so on. This study sorts out details of government subsidies in the notes to the annual report of enterprises through keyword selection and calculates the number of environmental subsidies received every year.

It chooses enterprise size, business age, debt ratio, asset structure, profitability, equity balance, and growth ability as control variables. The variable definition is shown in Table 1.

\section{Modeling}

To explore the impact of environmental subsidies on environmental technology innovation, this study constructs the following model by referring to the methods of existing literature (Guo 2018):

$$
\begin{aligned}
& Y_{i, t}\left(\text { LnGp }_{i, t}, \operatorname{lnGpti} i_{i, t}, \text { LnNgpti }_{i, t}\right)=\alpha_{0}+\alpha_{1} \text { Esub }_{i, t+1} \\
& +\alpha_{2} \text { Size }_{i, t-1}+\alpha_{3} \text { Age }_{i, t-1}+\alpha_{4} \text { Lev }_{i, t-1}+\alpha_{5} \text { Opr }_{i, t-1} \\
& +\alpha_{6} \text { Assets }_{i, t-1}+\alpha_{7} \text { Shareb }_{i, t-1}+\lambda_{i}+\tau_{t}+\varepsilon_{i, t}
\end{aligned}
$$

In the above formula (1), $Y$ represents the enterprise's environmental technology innovation behavior, which is measured by the number of applications for two types of patents. $I$ represents the enterprise. $T$ represents the time. $\alpha$ is the coefficient. $\varepsilon$ represents the error term. Definitions of other variables are shown in Table 1 . The control variables lag for one period to reduce the influence of endogenous. The reason why environmental subsidy is postponed is that there is a time lag of about one year between the government's appropriation to enterprises and the patent output. At the same time, to control the time-invariant impact and macro-economic impact at the enterprise level, $\lambda_{i}$ and $\tau_{t}$ are added. They represent the fixed effect and year fixed effect at the enterprise level. The study establishes a two-factor fixed effect regression model.

According to the requirements of panel data regression analysis, model selection is required. Therefore, the Haussmann test is carried out for each model. If the Haussmann test value is significant, the fixed-effect model is selected. If the Haussmann test value is not significant, the random effect model is selected. For cases that cannot be distinguished, the random effect model should also be selected.

Table 1: Variable definition.

\begin{tabular}{lll}
\hline Variable name & Code & Calculation instructions \\
\hline Total amount of environmental technology innovation & $\mathrm{Gp}$ & Ln (1+ environmental technology patent total number) \\
Environmental technology invention innovation & $\mathrm{Gpti}$ & $\mathrm{Ln}(1+$ number of environmental technology invention patents) \\
Other environmental technology innovations & $\mathrm{Ngpti}$ & Ln (1+ the number of other environmental technology patents) \\
Environmental subsidy & Esub & (Environmental subsidy/Total assets at the end of the period) $\times 100 \%$ \\
Enterprise size & Size & Ln (total assets) \\
Business age & Age & Number of years since the establishment of the company \\
Debt ratio & Lev & (Total Liabilities/Total Assets) $\times 100 \%$ \\
Asset structure & Assets & (Net fixed assets/Total assets) $\times 100 \%$ \\
Profitability & Opr & (Operating profit/Operating income) $\times 100 \%$ \\
Equity checks and balances & Shareb & The largest shareholder's shareholding ratio \\
Growth ability & Growth & Operating income growth rate \\
\hline
\end{tabular}




\section{RESULTS AND DISCUSSION}

\section{Model Selection}

Test statistics of the three models are significant at the $1 \%$ significance level, which shows that the fixed effect of each model is better than the random effect, which proves that the model setting is appropriate (see Table 2).

The estimated value of Esub coefficient in column (1) is significant at the level of $10 \%$, indicating that the number of environmental technology patent applications increases under the incentive of environmental subsidies. The estimated value of Esub coefficient in column (3) is less than the significant level of $10 \%$, and the estimated value of Esub coefficient in column (5) is significant at the level of 5\%, which indicates that the impact of environmental subsidies results in a significant increase in the number of non-invention patent applications. However, the number of invention patent applications is not significantly affected. This shows that under the incentive of selective environmental subsidies, enterprises show more patent applications to obtain subsidy resources to demonstrate innovation ability. Since enterprises can arrange innovation activities in advance to meet the preference of the government, to improve their chances of success, the increase of environmental technology innovation output is only a strategic behavior, reflecting the adverse selection motivation of enterprises to cater to policies and to seek support.

Table 2: Model selection.

\begin{tabular}{|c|c|c|c|c|c|c|}
\hline \multirow[t]{3}{*}{ Variable } & (1) & (2) & (3) & (4) & (5) & (6) \\
\hline & Model $1 \mathrm{FE}$ & Model 1 RE & Model 2 FE & Model 2 RE & Model 3 FE & Model 4 RE \\
\hline & Gp & $\mathrm{Gp}$ & Gpti & Gpti & Ngpti & Ngpti \\
\hline \multirow[t]{2}{*}{ Esub } & $0.0482^{*}$ & $0.104^{* * *}$ & 0.0391 & $0.0773^{* * *}$ & $0.0539^{* *}$ & $0.123^{* * *}$ \\
\hline & $(0.0290)$ & $(0.0280)$ & $(0.0280)$ & $(0.0269)$ & $(0.0257)$ & $(0.0246)$ \\
\hline \multirow[t]{2}{*}{ Size } & $0.123^{* * *}$ & $0.257^{* * *}$ & $0.158^{* * *}$ & $0.246^{* * *}$ & $0.0928^{* * * *}$ & $0.259^{* * *}$ \\
\hline & $(0.0361)$ & $(0.0254)$ & $(0.0348)$ & $(0.0245)$ & $(0.0320)$ & $(0.0214)$ \\
\hline \multirow[t]{2}{*}{ Age } & $-0.348^{* * *}$ & $-0.0494^{* * *}$ & $-0.355^{* * *}$ & $-0.0417^{* * *}$ & $-0.223^{* * *}$ & $-0.0255^{\text {*** }}$ \\
\hline & $(0.0343)$ & $(0.00748)$ & $(0.0331)$ & $(0.00722)$ & $(0.0304)$ & $(0.00594)$ \\
\hline \multirow[t]{2}{*}{ Lev } & $-0.224^{*}$ & $-0.266^{* *}$ & -0.185 & $-0.206^{*}$ & -0.0903 & -0.103 \\
\hline & $(0.121)$ & $(0.110)$ & $(0.117)$ & $(0.106)$ & $(0.107)$ & $(0.0958)$ \\
\hline \multirow[t]{2}{*}{ Assets } & $0.311^{*}$ & -0.0748 & 0.204 & -0.187 & 0.181 & -0.103 \\
\hline & $(0.161)$ & $(0.144)$ & $(0.155)$ & $(0.138)$ & $(0.142)$ & $(0.124)$ \\
\hline \multirow[t]{2}{*}{ Opr } & 0.261 & -0.00192 & $0.362^{*}$ & 0.187 & -0.148 & $-0.274^{*}$ \\
\hline & (0.209) & $(0.165)$ & $(0.202)$ & $(0.159)$ & $(0.185)$ & $(0.140)$ \\
\hline \multirow[t]{2}{*}{ Shareb } & $-0.00518^{* *}$ & -0.00130 & -0.00197 & 0.00108 & $-0.00500^{* *}$ & -0.00206 \\
\hline & $(0.00229)$ & $(0.00174)$ & $(0.00221)$ & $(0.00168)$ & $(0.00203)$ & $(0.00147)$ \\
\hline \multirow[t]{2}{*}{ Growth } & -0.0161 & -0.0160 & -0.0163 & -0.0175 & -0.00202 & -0.00573 \\
\hline & $(0.0421)$ & $(0.0415)$ & $(0.0407)$ & $(0.0399)$ & $(0.0373)$ & $(0.0366)$ \\
\hline \multirow[t]{2}{*}{ _cons } & $5.993^{* * *}$ & $-2.765^{* * *}$ & $4.702^{* * *}$ & $-3.364^{* * *}$ & $3.866^{* * *}$ & $-3.703^{* * *}$ \\
\hline & $(0.976)$ & $(0.567)$ & $(0.943)$ & $(0.547)$ & $(0.865)$ & $(0.473)$ \\
\hline $\mathrm{N}$ & 6180 & 6180 & 6180 & 6180 & 6180 & 6180 \\
\hline $\mathrm{R} 2$ & 0.051 & & 0.043 & & 0.050 & \\
\hline F Value & $20.40^{* * *}$ & & $17.21^{* * *}$ & & $19.87^{* * *}$ & \\
\hline Wald chi2 & & $386.77^{* * *}$ & & $333.09^{* * *}$ & & $419.76^{* * *}$ \\
\hline \multicolumn{7}{|c|}{ Hausman Test } \\
\hline Chi-square & 158.82 & & 181.53 & & 102.24 & \\
\hline P-Value & 0.0000 & & 0.0000 & & 0.0000 & \\
\hline
\end{tabular}

Note: Standard errors are in parentheses. *,**,*** represent the significance level of $10 \%, 5 \%$, and $1 \%$, respectively. 


\section{Heterogeneity Analysis}

Nature of ownership: The estimated value of Esub coefficient in columns (1) and (4) is significant; it means that the total environmental technology patent applications of both state-owned enterprises and private enterprises are not significantly affected by environmental subsidies (see Table 3 ). The estimated value of Esub coefficient in column (3) is significant at the level of $5 \%$, which indicates that the number of non-patent applications of state-owned enterprises has increased significantly under the incentive of environmental subsidies. The estimated value of Esub coefficient in column (2) is less than $10 \%$, indicating that the number of invention patent applications of state-owned enterprises has not been significantly affected. In contrast, the number of invention patent applications of private enterprises has increased significantly, and the estimated value of Esub coefficient in column (5) is significant at the level of $5 \%$. The estimated coefficient in column (6) is less than $10 \%$, indicating that the number of non-invention patent applications of private enterprises is not significantly affected.

The phenomenon means that compared with private enterprises, state-owned enterprises have less willingness to survive in the market by high-tech environmental technology invention patents. Selective industrial policy guides the increase of "quantity" rather than "quality" of environmental technology innovation of state-owned enterprises. Private enterprises are facing fierce market competition and they need high-quality technology innovation to win. Therefore, private enterprises need substantial environmental technology innovation, pay attention to the improvement of innovation quality. They will not blindly innovate to meet the policy and to strive for the subsidy resources that may or may not be available, resulting in the strategic behavior of only pursuing innovation "quantity".

Technical background of senior executives: When the government chooses innovation subsidy objects, it will rely

Table 3: Results Grouped by Ownership Nature.

\begin{tabular}{|c|c|c|c|c|c|c|}
\hline \multirow[t]{3}{*}{ Variable } & \multicolumn{3}{|c|}{ State-owned enterprise } & \multicolumn{3}{|c|}{ Private enterprise } \\
\hline & (1) & (2) & (3) & (4) & (5) & (6) \\
\hline & $\mathrm{Gp}$ & Gpti & Ngpti & $G p$ & Gpti & Ngpti \\
\hline \multirow[t]{2}{*}{ Esub } & 0.0679 & 0.0146 & $0.0943^{* *}$ & 0.0346 & $0.0735^{* *}$ & 0.00445 \\
\hline & $(0.0453)$ & $(0.0421)$ & $(0.0430)$ & $(0.0381)$ & $(0.0330)$ & $(0.0371)$ \\
\hline \multirow[t]{2}{*}{ Size } & $0.287^{* * *}$ & $0.216^{* * *}$ & $0.302^{* * *}$ & $0.109^{* *}$ & 0.0635 & $0.162^{* * *}$ \\
\hline & $(0.0631)$ & $(0.0586)$ & $(0.0599)$ & $(0.0509)$ & $(0.0440)$ & $(0.0495)$ \\
\hline \multirow[t]{2}{*}{ Age } & $-0.327^{* * *}$ & $-0.229^{* * * *}$ & $-0.350^{* * * *}$ & $-0.359^{* * *}$ & $-0.222^{* * *}$ & $-0.359^{* * *}$ \\
\hline & $(0.0582)$ & $(0.0541)$ & $(0.0553)$ & $(0.0430)$ & $(0.0373)$ & $(0.0419)$ \\
\hline \multirow[t]{2}{*}{ Lev } & -0.0324 & -0.0466 & -0.0458 & $-0.316^{*}$ & -0.120 & $-0.273^{*}$ \\
\hline & $(0.201)$ & $(0.187)$ & $(0.191)$ & $(0.162)$ & $(0.141)$ & $(0.158)$ \\
\hline \multirow[t]{2}{*}{ Assets } & $0.766^{* * *}$ & $0.691^{* * *}$ & $0.594^{* *}$ & 0.211 & 0.00654 & 0.137 \\
\hline & $(0.266)$ & $(0.247)$ & $(0.253)$ & $(0.214)$ & $(0.185)$ & $(0.208)$ \\
\hline \multirow[t]{2}{*}{ Opr } & -0.433 & $-0.656^{*}$ & -0.145 & $0.451^{*}$ & -0.0261 & $0.481^{*}$ \\
\hline & $(0.371)$ & $(0.344)$ & $(0.352)$ & $(0.264)$ & $(0.229)$ & $(0.257)$ \\
\hline \multirow[t]{2}{*}{ Shareb } & -0.000778 & -0.00135 & 0.00121 & $-0.00667^{* *}$ & $-0.00710^{* * * *}$ & -0.00230 \\
\hline & $(0.00401)$ & $(0.00373)$ & $(0.00381)$ & $(0.00294)$ & $(0.00255)$ & $(0.00286)$ \\
\hline \multirow[t]{2}{*}{ Growth } & -0.107 & -0.00711 & $-0.138^{*}$ & 0.0213 & 0.00692 & 0.0301 \\
\hline & $(0.0744)$ & $(0.0691)$ & $(0.0706)$ & $(0.0528)$ & $(0.0457)$ & $(0.0513)$ \\
\hline \multirow[t]{2}{*}{ _cons } & 2.817 & 2.014 & 2.182 & $6.048^{* * * *}$ & $4.174^{* * * *}$ & $4.274^{* * * *}$ \\
\hline & (1.860) & (1.728) & (1.766) & (1.240) & (1.074) & (1.207) \\
\hline $\mathrm{N}$ & 2164 & 2164 & 2164 & 4016 & 4016 & 4016 \\
\hline $\mathrm{R}^{2}$ & 0.079 & 0.075 & 0.072 & 0.045 & 0.041 & 0.038 \\
\hline F value & $11.55^{* * * *}$ & $10.89^{* * *}$ & $10.42^{* * * *}$ & $11.38^{\text {**** }}$ & $10.31^{* * * *}$ & $9.43^{* * *}$ \\
\hline
\end{tabular}

Note: Standard errors are in parentheses. ${ }^{*}, * *, * * *$ represent the significance level of $10 \%, 5 \%$, and $1 \%$, respectively. 
on some dominant signals to make decisions, to avoid the interference of information asymmetry. The technical R\&D background of the enterprise's top management team is the government's key consideration (Peng et al. 2017).

The estimated value of Esub coefficients in column (4), column (5), and column (6) of Table 4 do not reach the significance level of $10 \%$, indicating that the total number of environmental technology patents, invention patents and other patent applications of enterprises with no technical background of senior executives are not significantly affected by environmental subsidies. In contrast, the total number of environmental technology patent applications and the number of non-invention patent applications of enterprises with technical backgrounds have increased significantly. For example, the estimated value of Esub coefficient in column (1) is significant at the level of $10 \%$, and the estimated value of Esub coefficient in column (3) is significant at the level of $5 \%$. However, the estimated coefficient in column (2) does not reach the significance level of $10 \%$, indicating that the number of environmental technology invention patent applications of enterprises with technical backgrounds is not significantly affected by environmental subsidies.

This phenomenon shows that executives with technical R\&D backgrounds are more likely to consciously invest more capital in R\&D and technology innovation when allocating resources. Under the incentive of selective environmental subsidy, the top management team with professional background and experience chooses the non-invention patent declaration with lower difficulty, shorter R\&D cycle, and lower risk. The aim is to make the formulation and implementation of future environmental subsidy schemes more reliable, rather than blindly carrying out the high-quality innovation with high difficulty, long cycle, and high risk.

\section{Managerial Implications}

Polluting enterprises should increase investment in environmental technology innovation. In the practical application

Table 4: Results grouped by executive background.

\begin{tabular}{|c|c|c|c|c|c|c|}
\hline \multirow[t]{3}{*}{ Variable } & \multicolumn{3}{|c|}{ Executives with technical background } & \multicolumn{3}{|c|}{ Executives without technical background } \\
\hline & (1) & (2) & (3) & (4) & (5) & (6) \\
\hline & Gp & Gpti & Ngpti & $G p$ & Gpti & Ngpti \\
\hline \multirow[t]{2}{*}{ Esub } & $0.0506^{*}$ & 0.0394 & $0.0578^{* *}$ & 0.00614 & 0.0705 & 0.0115 \\
\hline & $(0.0304)$ & $(0.0293)$ & $(0.0273)$ & $(0.111)$ & $(0.107)$ & $(0.0901)$ \\
\hline \multirow[t]{2}{*}{ Size } & $0.126^{* * *}$ & $0.156^{* * *}$ & $0.0968^{* * *}$ & 0.0430 & 0.0380 & 0.0512 \\
\hline & $(0.0383)$ & $(0.0369)$ & $(0.0344)$ & $(0.135)$ & $(0.130)$ & $(0.110)$ \\
\hline \multirow[t]{2}{*}{ Age } & $-0.362^{* * *}$ & $-0.371^{* * *}$ & $-0.233^{* * *}$ & -0.243 & -0.159 & -0.191 \\
\hline & $(0.0355)$ & $(0.0342)$ & $(0.0318)$ & $(0.149)$ & $(0.144)$ & $(0.121)$ \\
\hline \multirow[t]{2}{*}{ Lev } & -0.0526 & -0.0467 & 0.0165 & -0.597 & -0.581 & -0.128 \\
\hline & $(0.132)$ & $(0.127)$ & (0.118) & $(0.404)$ & $(0.389)$ & $(0.329)$ \\
\hline \multirow[t]{2}{*}{ Assets } & 0.221 & 0.0880 & 0.198 & -0.00442 & 0.581 & -0.780 \\
\hline & $(0.170)$ & $(0.164)$ & $(0.153)$ & $(0.599)$ & $(0.576)$ & $(0.487)$ \\
\hline \multirow[t]{2}{*}{ Opr } & 0.193 & $0.362^{*}$ & -0.256 & 1.018 & 0.281 & 0.930 \\
\hline & $(0.220)$ & $(0.212)$ & (0.197) & (0.799) & $(0.769)$ & $(0.651)$ \\
\hline \multirow[t]{2}{*}{ Shareb } & $-0.00588^{* *}$ & -0.00127 & $-0.00649^{* * *}$ & -0.000793 & -0.00792 & 0.00484 \\
\hline & $(0.00249)$ & $(0.00239)$ & $(0.00223)$ & $(0.00765)$ & $(0.00737)$ & $(0.00623)$ \\
\hline \multirow[t]{2}{*}{ Growth } & -0.0173 & -0.0150 & -0.00246 & -0.0656 & -0.0229 & -0.0110 \\
\hline & $(0.0445)$ & $(0.0428)$ & (0.0398) & $(0.153)$ & $(0.148)$ & $(0.125)$ \\
\hline \multirow[t]{2}{*}{ _cons } & $6.223^{* * *}$ & $4.978^{* * * *}$ & $4.058^{* * *}$ & 5.072 & 3.775 & 3.087 \\
\hline & (1.024) & $(0.985)$ & (0.917) & $(4.041)$ & (3.890) & (3.289) \\
\hline $\mathrm{N}$ & 5661 & 5661 & 5661 & 519 & 519 & 519 \\
\hline $\mathrm{R}^{2}$ & 0.052 & 0.046 & 0.050 & 0.050 & 0.043 & 0.062 \\
\hline F value & $18.91^{* * * *}$ & $16.66^{* * *}$ & $18.11^{* * * *}$ & 1.37 & 1.18 & $1.73^{*}$ \\
\hline
\end{tabular}

Note: Standard errors are in parentheses. ${ }^{*}, * *, * * *$ represent the significance level of $10 \%, 5 \%$, and $1 \%$, respectively. 
of environmental protection, the continuous breakthrough of technologies including desulfurization and denitration, bag dust removal, and catalytic conversion can play a sustainable role in improving the environment. Therefore, polluting enterprises should pay attention to the continuous promotion of environmental technological innovation, improve the utilization efficiency of resources from the source and process, use efficient environmental protection equipment to save energy, and reduce environmental pollution, which will bring significant improvement in environmental performance.

In the process of implementing the environmental subsidies policy, the government should strictly control the pollution sources, and the relevant regulatory authorities should strengthen the implementation of energy conservation and emission reduction, formulate a more targeted regulatory system to control pollution emissions, and improve the regulatory efficiency in the innovation process. At the same time, the government should actively carry out public supervision of environmental pollution, encourage the public to participate in the complaints and suggestions of environmental pollution, open a network interactive platform and create a good atmosphere for environmental protection supervision.

The effectiveness of the environmental subsidy policy cannot be measured by only one performance index. We should build a more scientific performance evaluation system for enterprises of different nature and industries to comprehensively evaluate the effectiveness of the policy. Environmental subsidies should have a strict evaluation system, which involves not only the evaluation of economic performance but also the evaluation of social and environmental benefits. Design a reasonable and comprehensive analysis and evaluation system for different types of enterprises, and then build a reasonable and effective policy support model to maximize the use efficiency of government funds.

\section{CONCLUSIONS}

Environmental technology innovation is an important factor for polluting enterprises to achieve sustainable development and has an important impact on improving the quality of environmental protection. Based on the data of China's listed polluting enterprises from 2013 to 2019, the impact of environmental subsidies on environmental technology innovation of enterprises from the perspective of selective industrial policy was discussed and the heterogeneous impact of the nature of enterprise ownership and the technical background of executives was analyzed. Following conclusions are drawn.

(1) Environmental subsidies promote the overall growth of environmental technology patent applications of polluting enterprises. Among them, the number of invention patents representing the high-tech level is not significantly affected, while the number of non-invention patents increases significantly. It shows the phenomenon of pursuing quantity while ignoring the quality of environmental technology innovation.

(2) From the perspective of enterprise property rights, environmental subsidies significantly increase the number of non-invention patent applications of state-owned enterprises. They also significantly increase the number of invention patent applications of private enterprises but have no significant impact on other aspects.

(3) From the perspective of whether the senior executives with technical background, the total number of patent applications and the number of non-invention patent applications of enterprises with senior executives of technical background increase significantly. However, the number of invention patents and enterprises without senior executives of technical background is not significantly affected by environmental subsidies.

(4) From the perspective of selective industrial policy, there is a phenomenon that enterprises use environmental technology innovation strategy to cater to the government and to seek support. In terms of motivation, it is an innovation strategy rather than a substantial innovation.

\section{ACKNOWLEDGMENT}

This study was supported by the Henan Soft Science Project (182400410659), and the Doctoral Fund Project of Henan University of Engineering (D2017027).

\section{REFERENCES}

Cormier, D. and Magnan, M. 2015. The economic relevance of environmental disclosure and its impact on corporate legitimacy: An empirical investigation. Business Strategy \& the Environment, 24(6): 431-450.

Guo, Y. 2018. Signal transmission mechanism of government innovation subsidy and enterprise innovation. China Industrial Economics, (9): 98-116.

Hall, B. H. and Harhoff, D. 2012. Recent research on the economics of patents. Annual Review of Economics, 4(1): 541-565.

Jiang, F.T. and Li, X.P. 2010. Direct market intervention and restrict competition: the orientation of China's industrial policy and its fundamental defects. China Industrial Economics, (9): 26-36.

Li, D., Zheng, M., Cao, C., Chen, X., Ren, S. and Huang, M. 2017. The impact of legitimacy pressure and corporate profitability on green innovation: evidence from China's top 100. Journal of Cleaner Production, (141): 41-49.

Li, W.J. and Zheng, M.N. 2016. Is it substantive innovation or strategic innovation: impact of macroeconomic policies on micro-enterprises' innovation. Economic Research Journal, (4): 60-73.

Luo, S. and Sun, Y. 2020. Do selective R \& D incentives from the government promote substantive innovation? Evidence from Shanghai technological enterprises. Asian Journal of Technology Innovation, 28(3): 323-342. 
Mao, Q.L. and Xu, J.Y. 2015. The effect of government subsidy on firms' new product innovation: an analysis based on the moderate interval of subsidy intensity. China Industrial Economics, (6): 94-107.

Peng, H.X. and Mao, X.S. 2017. Government subsidies for innovation, company executives background and R\&D investment: evidence from the high-tech industry. Finance \& Trade Economics, (3): 147-161.

Wang, X. and Wang, L. 2020. The major shareholders unavoidable: a new explanation for the failure of government subsidies on green innovation. R\&D Management, (2): 24-36.

Xie, X., Huo, J. and Zou, H. 2019. Green process innovation, green product innovation, and corporate financial performance: a content analysis method. Journal of Business Research, 101(8): 697-706.

Yu, Z.M. 2021. Environmental protection interview, government environmental protection subsidies and enterprise green innovation. Foreign Economics \& Management, (7): 22-37. 